\title{
An Analysis on Bullying Behaviors of the Sports Spectator Students of Faculty of Sports Sciences
}

\author{
Yahya Doğar ${ }^{1}$, Yasin Karaca ${ }^{2}$ \\ ${ }^{1}$ Inonu University, Faculty of Sports Sciences, Turkey \\ ${ }^{2}$ Ministry of National Education, Turkey \\ Correspondence: Yahya Doğar, Inonu University, Faculty of Sports Sciences, Turkey.
}

$\begin{array}{lc}\text { Received: July 24, } 2019 & \text { Accepted: August 12, } 2019 \quad \text { Online Published: August 25, } 2019 \\ \text { doi:10.11114/jets.v7i11.4484 } & \text { URL: https://doi.org/10.11114/jets.v7i11.4484 }\end{array}$

\begin{abstract}
The aim of the study is to assess the effects of various variables of the relationship among bullying behaviors of students who are sports spectators studying in the Faculty of Sports Sciences. Quantitative method and survey model have been used in order to define and explain the existing cases in the study. Descriptive method has been used to determine the bullying behavior levels of 311 male and 117 female students studying in the Faculties of Sports Sciences of Ataturk and Inonu Universities in 2018-2019 academic year. In order to analyze the relationship between both variables in the research on the other hand, a relational method has been used. "Bullying Scale of Sports Spectators" has also been used in the research as a data collection tool (Karaca, 2019). The type of scale is one-dimensional five point Likert scale and it comprises 15 questions. Both survey and relational models have been used in the study. There are significant differences found with respect to the variables: Gender, department of study, family income and education statuses, places to spectate the matches and their frequency, attending away matches and lastly memberships to fan clubs. On the other hand, there is no significant difference found between bullying behavior and the ages of students, their social media account ownerships, their social media usage purposes and the devices they use for their social media accounts.
\end{abstract}

Keywords: bullying, faculty of sports sciences students, bullying and sports spectators

\section{Introduction}

Sports competitions can transform from being a competition for especially young spectators into an inspiration for shaping psychological and political individuality and status. Naturally, such an environment gives a chance to turn the emotions and thoughts of sports spectators to such behaviors, which cannot be normally expressed by them due to cultural and moral oppression. One of the various negative behaviors, which can arise after the expression of these emotions and thoughts, is bullying.

According to Olweus (1999), in order for an action to be considered as bullying, the three basic qualities are needed: Intentional violent behavior targeted towards the individual(s) in the position of prey with the purpose of harming them, the behavior showing continuity and lastly a disequilibrium of power present between the bully and the victim.

Stein et al. (2007) mention that the imbalance of power can be physical as well as psychological. Berger on the other hand (2007) claims; random friendly banter or disrupting behavior is not considered as bullying, but offending behavior is considered as bullying.

Bullying is generally handled under two main headings: direct bullying and indirect bullying, depending on the way the bully turns to the victim. Direct bullying generally includes physical contact and comprises of situations such as shoving, hitting, kicking, strangling, injuring and vandalizing or stealing the property of someone else. The actions in indirect bullying occur generally with the absence of physical contact and they are aimed at psychologically hurting the person's control mechanisms. The examples for this category can be summarized as calling the name repetitively, mocking, swearing, threating, humiliation, spreading rumors or disrupting writings-notes and social exclusion (Buch, 2012).

In spite of the different types of bullying mentioned in the literature, the classification made by Olweus is generally the one that is most commonly used. Olweus (1993) mentions about three types of bullying; physical, verbal and social: 
Since verbal and physical bullying are observable, they are classified as direct bullying, whereas social exclusion is defined to be indirect bullying. According to Crick and Bigbee (1998), while directly subjected bullying includes an open assault directed to the victim; the indirect bullying consists of behaviors such as leaving the victim alone, excluding him/her from the group and spreading rumors.

It is identified that the children who have been subjected to bullying by their peers in schools are uneasy, depressed and upset, having difficulties in adapting to society, showing erratic behaviors physically and complaining from depression and psychosomatic symptoms (Fekkes, M., Pijpers, F. and Verlove-Vonherick, S.P. 2004; Natvig, G.K., Albregtsen, G. and Qvarnstrom, U. 2001.)

It is found out in a study comparing the bullying, victim and neutral students by Kumpulainen, K., Rasanen, E. and Puura, K. (2001) that both the bully and the victim students have a tendency to have psychological disorders in comparison to the students who are not involved in bullying behaviors. The most commonly seen disorders are attention deficit, behavioral disorder and depression. As for Mishna (2003), it is stated that the children, displaying bullying behaviors, have a tendency to experience sadness and attention deficit while the victim children are experiencing difficulties about fitting in and exclusions.

It is clear that not only the victim but also the bully will be harmed from bullying behavior. Farrington, (1993) while underlining that both of the victims and bullies are getting hurt by these actions at the same time, points out that the bullying actions of students, recognizing bullying as a habit, would not be limited to the school years. The situation becomes even more significant, particularly given that young individuals sometimes cannot perceive the disequilibrium of power among their friends as bullying and cannot realize that they are exposed to bullying. For this reason, the point of views and behaviors of young individuals on bullying need to be studied further.

In spite of various studies on bullying in recent years, it is seen that their focus is generally on young adults (Akada \& Kabasakal, 2018). Since the bullying behavior can be encountered in any period starting from younger ages to university and work life, conducted studies on bullying behavior in universities and especially among the university students who study sports education, are seen as beneficial for the prevention of it.

In this study, the bullying behaviors of sports spectators who are students of Faculty of Sports Sciences studying in two different universities in 2018-2019 academic year are investigated. The topics of how these behaviors occur and which variables are in effect are studied. Accordingly, the aim of this study is to reveal whether there is a significant difference in the relation between bullying behaviors and variables such as: Age, gender, family income and education levels, platforms to spectate the matches and their frequency, attending away matches, membership to fan clubs, having social media accounts, the purpose of using social media accounts and use frequency.

\section{Method}

\subsection{Model of the Research}

Quantitative method and survey model have been used in order to define and explain the existing cases in the study. Survey model is a studying approach used for defining a former or existing situation as it is. The individual, the event or the object, discussed in the study is to be defined within its own conditions as it is. The important thing is to be able to "observe" and "determine" what is wanted to be known (Karasar, 1998).

\subsection{Research Group}

The study group consists of 311 males and 127 females, which adds up to 438 sports spectator students who are studying in Ataturk and Inonu Universities Faculty of Sport Sciences in the academic year of 2018-2019.

\subsection{Data Collection Instruments}

As a data collecting instrument, "Bullying Scale of Sports Spectators" developed by Karaca (2019) is used in this study. The scale consists of 15 questions and is one dimensional with the type of five point likert scale. The scores obtained in the scale are between 1 and 5 and the increase in the scores indicates the increase in bullying.

For conducting the poll, the schools were visited by the researcher and associates after the necessary legal permits were taken. The poll was conducted on a voluntary basis. Following the necessary explanations about the purpose and filling directions of the poll, the poll was handed out to the sports spectator students.

\subsection{Data Analysis}

Raw data collected were loaded to the statistical package program. As seen on Table 1, it is observed that skewness and kurtosis values of points of the dependent variable (bullying) are interchanging between +1 and -1 . At this stage, since it is observed that dependent variables have normal distribution, T-Test is used for paired comparisons, ANOVA is used for multiple comparisons and Tukey Test is used for post hoc test. The significance level is chosen as , 05 . 
The raw data gathered are presented as crosstabs along with their averages, standard deviations and with their statistical processes. The skewness and kurtosis values of data of independent variables are reviewed. As seen on the table below, since the skewness values are within the interval of +2 and -2, parametric tests of Independent Sample T Test and One Way Anova are used (Tabachnich \& Fidell, 2013; George \& Mallery, 2010). Following the Anova Test, LSD test is used as post hoc test.

Table 1. The Skewness and Kurtosis Values of Bullying Points

\begin{tabular}{lccccccc}
\hline & \multirow{n}{*}{} & $\overline{\mathbf{X}}$ & \multirow{2}{*}{ SD } & \multicolumn{2}{c}{ Skewness } & \multicolumn{2}{c}{ Kurtosis } \\
& & & & Statistic & S. error & Statistic & S. error \\
Bullying Points & 438 & 1,84 & 0,78 & 1,342 & 0,117 & 1,992 & 0,223 \\
\hline
\end{tabular}

\section{Findings}

Table 2. Bullying Behaviors of FSS Students with Respect To Their Gender

\begin{tabular}{lccccc}
\hline Gender & $\mathbf{N}$ & $\overline{\mathbf{X}}$ & $\mathbf{S D}$ & $\mathbf{T}$ Test & $\mathbf{P}$ \\
\hline Male & 311 & 1,9481 &, 80814 & & \\
Female & 127 & 1,6080 &, 67655 & 4,181 & $0,00^{*}$ \\
Total & 438 & 1,8495 &, 78685 & & \\
\hline
\end{tabular}

$* \mathrm{p}<0,05$

A significant relationship is found with respect to the genders of students in Table 2.

Table 3. Bullying Behaviors of FSS Students With Respect To Age Variable

\begin{tabular}{lcccccc}
\hline Age & $\mathbf{N}$ & $\overline{\mathbf{X}}$ & SD & F & ANOVA & \\
\hline $18-20$ & 84 & 1,9481 &, 83295 & & \\
$21-25$ & 318 & 1,8363 &, 79087 & 1,079 & 0,341 \\
$26-35$ & 36 & 1,7361 &, 61796 & & \\
Total & 438 & 1,8495 &, 78685 & & \\
$* \mathrm{p}>0,05$ & & &
\end{tabular}

No significant relationship is found with respect to the age variable in Table 3.

Table 4. Bullying Behaviors of FSS Students with Respect To the Department Variable

\begin{tabular}{|c|c|c|c|c|c|c|c|}
\hline \multirow{2}{*}{ Department } & \multirow{2}{*}{$\mathbf{N}$} & \multirow{2}{*}{$\overline{\mathbf{X}}$} & \multirow{2}{*}{ SD } & \multicolumn{2}{|c|}{ ANOVA } & \multicolumn{2}{|c|}{ LSD (Post hoc) } \\
\hline & & & & $\mathbf{F}$ & $\mathbf{p}$ & Group & $\mathbf{p}$ \\
\hline Sports Coaching (1) & 158 & 2,0692 & ,92685 & & & $1-2$ & $0,000^{*}$ \\
\hline Sports Teaching (2) & 163 & 1,6345 & ,58893 & & & $1-3$ & $0,021 *$ \\
\hline Sports Management (3) & 117 & 1,8523 & ,74478 & 12,908 & $0,000^{*}$ & $2-3$ & $0,019 *$ \\
\hline Total & 438 & 1,8495 &, 78685 & & & & \\
\hline
\end{tabular}

A significant relationship is found in Table 4 about the bullying behavior of FSS students with respect to the departments they study.

Table 5. Bullying Behaviors of FSS Students with Respect to the Monthly Income of Their Families

\begin{tabular}{lrcccccc}
\hline \multirow{2}{*}{ Family Monthly Income } & \multirow{2}{*}{$\mathbf{N}$} & $\overline{\mathbf{X}}$ & SD & \multicolumn{2}{c}{ ANOVA } & \multicolumn{2}{c}{ LSD (Post hoc) } \\
& & & & F & $\mathbf{p}$ & Group & $\mathbf{p}$ \\
\hline 0-2020 TL (min wage.) & 130 & 1,6731 &, 67094 & & & $1-2$ & $0,035^{*}$ \\
2021-4000TL & 211 & 1,8558 &, 72763 & & & $1-3$ & $0,000^{*}$ \\
4001-18000TL & 97 & 2,0722 &, 98130 & 7,367 & $0,001^{*}$ & $2-3$ & $0,023^{*}$ \\
Total & 438 & 1,8495 &, 78685 & & & & \\
\hline 05 & & & & & &
\end{tabular}

A significant relationship is found in Table 5 about the bullying behavior of students with respect to their families' income. 
Table 6. Bullying Behaviors of FSS Students with Respect to the Education Level of Their Fathers

\begin{tabular}{|c|c|c|c|c|c|c|c|}
\hline \multirow{2}{*}{ Father Education } & \multirow{2}{*}{$\mathbf{N}$} & \multirow{2}{*}{$\overline{\mathbf{X}}$} & \multirow{2}{*}{ SD } & \multicolumn{2}{|c|}{ ANOVA } & \multicolumn{2}{|c|}{ LSD (Post hoc) } \\
\hline & & & & $\mathbf{F}$ & $\mathbf{p}$ & Group & $\mathbf{p}$ \\
\hline Primary (1) & 167 & 1,7181 &, 70433 & & & & \\
\hline Secondary (2) & 85 & 1,9244 & ,73749 & & & $1-2$ & $0,048^{*}$ \\
\hline High School (3) & 133 & 1,8668 &, 75120 & 3,683 & $0,012 *$ & $1-4$ & $0,002 *$ \\
\hline University (4) & 53 & 2,0997 & 1,08592 & & & & \\
\hline Total & 438 & 1,8495 &, 78685 & & & & \\
\hline
\end{tabular}

A significant relationship is found in Table 6 with respect to the education levels of fathers.

Table 7. Bullying Behaviors of FSS Students with Respect to the Education Level of Their Mothers

\begin{tabular}{lrcccccc}
\hline Mother Education & \multicolumn{1}{c}{ N } & $\overline{\mathbf{X}}$ & SD & \multicolumn{2}{c}{ ANOVA } & \multicolumn{2}{c}{ LSD (Post hoc) } \\
Primary (1) & 248 & 1,7823 &, 73182 & & & & Group \\
Secondary (2) & 83 & 1,8287 &, 68320 & & & $1-4$ & $0,000^{*}$ \\
High School (3) & 74 & 1,8880 &, 87945 & 4,740 & $0,003^{*}$ & $2-4$ & $0,002^{*}$ \\
University (4) & 33 & 2,3203 & 1,04523 & & & $3-4$ & $0,008^{*}$ \\
Total & 438 & 1,8495 &, 78685 & & & & \\
\hline 0,05 & & & & & & &
\end{tabular}

A significant relationship is found in Table 7 with respect to the education levels of mothers.

Table 8. Bullying Behaviors of FSS Students with Respect to the Platforms or Places that the Students Watch the Games

\begin{tabular}{lrcccccc}
\hline Watching Games & \multicolumn{1}{c}{ N } & $\overline{\mathbf{X}}$ & SD & \multicolumn{2}{c}{ ANOVA } & \multicolumn{2}{c}{ LSD (Post hoc) } \\
Stadium (1) & 45 & 2,2762 &, 99635 & & & & \\
TV(2) & 143 & 1,7373 &, 68719 & & & $1-2$ & $0,000^{*}$ \\
Internet (3) & 132 & 1,8490 &, 70250 & & & $1-3$ & $0,001^{*}$ \\
All (4) & 83 & 1,9019 &, 87757 & 4,939 & $0,001^{*}$ & $1-4$ & $0,009^{*}$ \\
None (5) & 35 & 1,6367 &, 77114 & & & $1-5$ & $0,000^{*}$ \\
Total & 438 & 1,8495 &, 78685 & & & & \\
\hline
\end{tabular}

$* \mathrm{p}<0,05$

No significant relation is seen on Table 8 with respect to the places that the students watch the games.

Table 9. Bullying Behaviors of FSS Students with Respect to Frequency of Watching Games

\begin{tabular}{|c|c|c|c|c|c|c|c|}
\hline \multirow{2}{*}{$\begin{array}{l}\text { Frequency of } \\
\text { Watching Games }\end{array}$} & \multirow{2}{*}{$\mathbf{N}$} & \multirow{2}{*}{$\overline{\mathbf{X}}$} & \multirow{2}{*}{ SD } & \multicolumn{2}{|c|}{ ANOVA } & \multicolumn{2}{|c|}{ LSD (Post hoc) } \\
\hline & & & & $\mathbf{F}$ & $\mathbf{p}$ & Group & $\mathbf{p}$ \\
\hline Regularly (1) & 67 & 2,2431 & 1,01184 & \multirow{5}{*}{6,546} & \multirow{5}{*}{$0,000^{*}$} & & \\
\hline Frequently (2) & 102 & 1,8873 &, 76453 & & & $1-2$ & $0,003 *$ \\
\hline Time to Time (3) & 168 & 1,7917 & ,72137 & & & $1-3$ & $0,000^{*}$ \\
\hline Rarely (4) & 80 & 1,6679 & ,55922 & & & $1-4$ & $0,000^{*}$ \\
\hline None (5) & 21 & 1,5646 & ,91971 & & & $1-5$ & $0,000^{*}$ \\
\hline Total & 438 & 1,8495 & ,78685 & & & & \\
\hline
\end{tabular}

A significant relationship is found in Table 9 related to the frequency of students watching the games. 
Table 10. Bullying Behaviors of FSS Students with Respect to the Frequency of Attending Away Matches

\begin{tabular}{|c|c|c|c|c|c|c|c|c|}
\hline \multirow{2}{*}{$\begin{array}{l}\text { Frequency } \\
\text { Attending } \\
\text { Matches }\end{array}$} & \multirow{2}{*}{$\begin{array}{r}\text { of } \\
\text { Away }\end{array}$} & \multirow[b]{2}{*}{$\mathbf{N}$} & \multirow[b]{2}{*}{$\overline{\mathbf{X}}$} & \multirow[b]{2}{*}{ SD } & \multicolumn{2}{|c|}{ ANOVA } & \multicolumn{2}{|c|}{ LSD (Post hoc) } \\
\hline & & & & & $\mathbf{F}$ & $\mathbf{p}$ & Group & $\mathbf{p}$ \\
\hline Always (1) & & 21 & 2,6939 & 1,09525 & & & & \\
\hline Frequently (2) & & 29 & 1,9138 & ,83526 & & & $1-2$ & $0,000^{*}$ \\
\hline Time to Time (3) & & 139 & 1,8679 & ,81354 & 9,768 & $0,000^{*}$ & $1-3$ & $0,000^{*}$ \\
\hline Rarely (4) & & 249 & 1,7605 & ,69150 & & & $1-4$ & $0,000^{*}$ \\
\hline Total & & 438 & 1,8495 & ,78685 & & & & \\
\hline
\end{tabular}

A significant relationship is found in Table 10 with respect to the frequency of students attending away matches.

Table 11. Bullying Behaviors of FSS Students with Respect to Their Membership to Fan Clubs

\begin{tabular}{|c|c|c|c|c|c|}
\hline Fan Club Membership & $\mathbf{N}$ & $\overline{\mathbf{X}}$ & SD & T Test & $\mathbf{P}$ \\
\hline Yes & 81 & 2,1887 & 1,02316 & & \\
\hline No & 357 & 1,7725 & ,70188 & 4,387 & $0,000^{*}$ \\
\hline Total & 438 & 1,8495 & ,78685 & & \\
\hline
\end{tabular}

A significant relationship is found in Table 11 with respect to the students' membership status to fan clubs.

Table 12. Bullying Behaviors of FSS Students with Respect to Having Social Media Accounts

\begin{tabular}{lccccc}
\hline Social Media Account & $\mathbf{N}$ & $\overline{\mathbf{X}}$ & SD & T Test & P \\
Yes & 412 & 1,8507 &, 78687 & & \\
No & 26 & 1,8297 &, 80180 & 0,132 & 0,895 \\
Total & 438 & 1,8495 &, 78685 & & \\
\hline
\end{tabular}

$\mathrm{p}>0,05$

No significant difference is found in Table 12 with respect to the students having social media accounts.

Table 13. Bullying Behaviors of FSS Students with Respect to the Intended Purpose of Their Social Media Accounts

\begin{tabular}{lrrrrr}
\hline Intended Purpose & N & $\overline{\mathbf{X}}$ & SS & \multicolumn{2}{c}{ ANOVA } \\
Entertainment & 243 & 1,8898 &, 87296 & & $\mathbf{p}$ \\
Messaging & 88 & 1,7468 &, 59505 & & \\
Voice and Visual Sharing & 65 & 1,8802 &, 68908 & 0,841 & 0,472 \\
None & 42 & 1,7840 &, 75519 & & \\
Total & 438 & 1,8495 &, 78685 & & \\
\hline
\end{tabular}

$\mathrm{p}>0,05$

No significant difference is found in Table 13 about the students' purposes of use of their social media accounts.

Table 14. Bullying Behaviors of FSS Students with Respect to the Devices They Use for Their Social Media Accounts

\begin{tabular}{lcccccc}
\hline Device Type & $\mathbf{N}$ & $\overline{\mathbf{X}}$ & $\mathbf{S D}$ & \multirow{2}{*}{ ANOVA } & $\mathbf{\text { F }}$ \\
Smartphone & 410 & 1,8460 &, 78644 & & & $\mathbf{}$ \\
Tablet and Computer & 19 & 1,9737 &, 90733 & & & \\
None & 9 & 1,7460 &, 54645 & 0,318 & & 0,728 \\
Total & 438 & 1,8495 &, 78685 & & & \\
\hline
\end{tabular}

$\mathrm{p}>0,05$

No significant difference is found in Table 14 about the type of devices students use for their social media accounts. 


\section{Discussion and Conclusion}

It is seen that most of the FSS students, spectating games and who participated in this study, consist of males (\%71). It is determined that average bullying points of female students are lower than male students. According to this data, it is appropriate to state that males show more bullying behavior than females (Table 2).

Duyar (2011), Koç (2006), Scheithauer et al. (2006), Pellegrini and Long (2002), Genç (2007), Sipahi (2008), Barboza et al. (2009) and Atalay (2010) suggested that bullying is mostly expressed by males. Bullying is mostly done by male students because they see it as a means of expressing themselves and resolving conflicts (İfaner, 2009). The higher occurrence of bullying behavior in males get along with a higher aggressiveness, while also setting forth its role in socialization. Bullying behavior expressed by males might be seen as a way of facilitating acceptance by peer groups and a way of achieving higher social status. For example, violent and bullying behaviors can sometimes be considered as "manly" behaviors by societies.Additionally, it can be said that the implicit pressure on women lead men to display bullying behavior in physical manner, while leading women not to do the same, but rather display verbal bullying behaviors. These results indicate that women display bullying behaviors less compared to men, but they show tendency to do it both individually and in groups.

There is no significant difference determined according to the ages of FSS students (Table 3). The occurrence of such a situation may be due to the fact that students are generally over 20 years of age and the age ranges are not too high.

Looking at similar studies, a close relation can be seen between the bullying and age. Olweus (1993) suggests that occurrences of bullying increase at the start of puberty among males as a result of exercising influence over their peers and earning respect efforts. Craig and Pepler (2003), along with Frisen, A., Jonsson, A. and Persson, C. (2007) stated that the start of bullying behavior is most commonly seen at the ages of 9,10 , and 11 . Some studies show that the frequency of bullying decreases in parallel with the age factor. Craig (1998) observed that physical bullying is decreasing with age. Study results of Nansel et al. (2001), Pellegrini and Long (2002) and Atalay's (2010) are in furtherance of the findings of this study. Hanish and Guerra (2000) along with Batsche and Knoff (1994), while explaining the occurrence of being bullied decreases with age, they state that bullies are specifically targeting juniors and defenseless people.

It is seen that there is a significant relationship between the bullying behavior of FSS students and the departments they study (Table 4). It is understood that coaching department students show an increased bullying behavior against sports teaching and sports management department students while sports teaching department students show an increased bullying behavior against sports management department students. In this situation, it can be said that an increase in exercising sports also means an increase in bullying behavior.

A significant relationship is found between the average monthly income of the student families and bullying behavior (Table 5). As the incomes of families increase, bullying behavior of students also resembles an increase. A similar situation is also seen about the education levels of students' mothers and fathers. As the education level of father and mother increases, an increase in bullying behavior of students is also found (Table 6, 7). However, if the studies on the relationship between bullying behavior and education levels of parents are reviewed, the results obtained are not corresponding to the findings of this study.Ekşisu, (2009) mentions that the children of families with low level of education are also showing an increased bullying behavior. Bayraktar, on the other hand, (2009) determined that the children of families with low level of education are more subjected to bullying. Satan (2006) suggested that there is no significant difference between the education levels of parents and bullying behavior, self-confidence and avoiding bullying.

According to Table 8, there is a significant difference in bullying behaviors of FSS students according to their places of choice in spectating games. It is understood that the students spectating the matches from stadiums show more bullying behavior compared to the students who are spectating the matches from TV, Internet, all devices and students who do not spectate the matches at all. Wakefield and Sloan (1995) express that the spectators who are affiliated to the team they support are spending more time on the stadium. This situation corresponds to the results of the study.

According to Table 9, a significant relationship is observable between FSS students spectating the matches and their bullying behavior. It is understood that the students who are spectating the matches regularly show an increased bullying behavior as regards to other students. The relation between sports spectators and bullying should not be solely limited to the place of sports exercised. The students can even spectate the matches, with their smartphones with internet connection thanks to the technological advancements. Through the internet and the online environment accessed by their smartphones, the spectators can make instant shares about the matches in written or visual form. The football matches being closer to the spectators as a smartphone in their pockets, make it easier for students to do bullying in every place they are in and extend the area of bullying.

A significant difference is found between frequency of attending away matches and bullying behavior in FSS students 
(Table 10). It is understood that the students who never miss any away matches exercise more bullying behavior than other students do. Turgut (2006) points out the $72.3 \%$ of the spectators are watching all the home matches of the team they are supporting while $19 \%$ of the spectators are only watching the important home matches. Baş (2008) determined that $34,4 \%$ of the spectators are watching every home match, $31,5 \%$ of the spectators are frequently watching home matches and $16,7 \%$ of the spectators are rarely watching home matches of the team they are supporting. Aycan, A., Polat, E. and Ucan, Y. (2009), point out in their study that $43 \%$ of the spectators are watching home matches of the team they are supporting and $49 \%$ of the spectators are watching away matches of the team they are supporting regularly.

According to Table 11, it is understood that FSS students who are members of a fan club are exercising more bullying behavior than the students who do not have a membership. The data obtained show that being a member to a fan club is effective in the increase of bullying levels of FSS students.

Affiliation with a group might be an important factor in terms of bullying behavior exercised as a group. The person might see no drawback in exercising a bullying behavior, which he/she cannot exercise when alone. The reason behind this is that being in a group shadows the individual's identity and may eliminate the self-control. Thus, this situation may decrease the sense of personal obligations (Mann, 1981). Not seeing the adversary as a person, the idea of us and them causes an occurrence of discrimination between the adversary and the individual. This perspective conduce towards a process of exclusion, rejection and misidentification for self and for others among the spectators (Wann, 1998).

There is no significant difference seen on whether the FSS students having social media accounts or not, in accordance to their bullying behavior (Table 12). Considering the social media usage statistics in Turkey, it is stated that there are 51 million social media users present in the country and 44 million of those users are connected to social media by mobile devices. It is indicated that the most widely used media platforms are YouTube, Facebook, Instagram and Twitter (Salih, 2018). Within this context, it can be said that the time spent on social media platforms and the circle formed in this environment are affecting and even promoting bullying. Just like other individuals, the football audience widely use social media, as well. This environment causes them to reflect the bullying behaviors on internet. It can even be said that it encourages bullying due to the convenience in means of access. This is because online environment and the social media are effective in shadowing the individuals as they are expressing their thoughts and emotions. Social media is used as a tool for revealing such feelings. Considering that the football audience watch football games for entertainment, tension release and relaxing, it can be said that the audience, who cannot feel satisfied with regards to showing these feelings under normal circumstances, may try to display cyber bullying behaviors on internet environment. In fact, there are videos and photos that show the large part of football audience to engage in both general and cyber bullying behaviors by means of swearing, mocking and fighting. These videos and photos can be accessed by millions of social media users through online media and social media platforms, which may lead to encouraging the bullying behavior. Moreover, it may not be possible to clearly understand the type of impact that such content may lead on individuals.

There is no significant difference found between the social media account usage purposes of FSS students and their bullying behavior (Table 13). A study conducted by the Ministry of Youth and Sports states that nearly half of the youth are using social media as means to pass free time, contacting, following and creating the agenda and such (GSB, 2014). It is seen that social media is used effectively mostly among young individuals (Lenhart, 2007). It is found out that individuals use social media for communication, playing games, making various shares, developing interpersonal relations, shopping and similar purposes (Tham, A. Croy, G. Mair, J.. 2013). Babacan (2015) declares that a great majority of young people is using social media as an entertainment medium and shares certain contents. This result coincides with the findings of this study.

According to Table 14, there is no significant difference seen between the device types FSS students use for their social media accounts and bullying behavior. It is understood that the commonly used device for reaching social media are smartphones among the students. Looking at similar studies, it can be seen that there are not many variables related to the devices used for reaching social media. Serin (2012) and Süslü (2016) determined that there is no significant difference between the type of devices used for reaching social media and bullying behaviors. The results obtained bear similarities with the findings of this study. Looking at the 2018's electronic device usage statistics in Turkey; it is seen that while $98 \%$ of the adults are using mobile phones, $77 \%$ of them are smartphone users. While the rate of desktop or laptop users are $48 \%$, the rate of tablet users are at $25 \%$. It is also found that the daily average time spent on internet by people is 7 hours. 2 hours 48 minutes of this time is spent on social media. It is determined that there are 54 million internet users in Turkey, which corresponds to $67 \%$ of the population, and 51 million of them have phones, which are connected to the internet (Bayrak, 2019).

As a result, it is understood that male FSS sports spectators students express more bullying behavior with regard to female students, Coaching Department students have more bullying behavior with regard to Teaching and Management Department students and as the level of income and education of the families increase, the bullying levels also increase. It 
was concluded that the students who spectated matches from the stadium had higher bullying behavior levels than the students who watched matches from other platforms, the students who watched the matches regularly had higher bullying levels than other students, the students who always attend to away matches had higher bullying levels than other students and students who are members of fan clubs had higher bullying levels than students who are not members of fan clubs. On the other hand, there is no significant difference observed in bullying behaviors among male and female students in accordance with the age, having social media accounts, the purpose of using their social media accounts and the type of device used.

In line with all the findings, conducting similar studies among the students of all universities, which include departments, faculties or institutes for sports education, might be important for a more accurate determination of bullying behaviors. Considering that the factors that affect bullying behaviors of students, may also trigger bullying behaviors towards society, which would be hard to drawback, a more detailed and in-depth investigations are necessary for public health.

\section{References}

Akada, T., \& Kabakasal, Z. (2018). "Siber Zorbalik Ve Universite Ogrencilerine İliskin Bir Degerlendirme", International Social Sciences Studies Journal, 4(24), 4977-4993. https://doi.org/10.26449/sssj.961

Atalay, A. (2010). Akran Zorbaligi Gosterme ve Akran Zorbaligina Maruz Kalmanin Cinsiyet, Yas Sosyo ekonomik Duzey, Anne-Baba Tutumlari, Arkadas Iliskileri ve Benlik Saygisi ile Iliskisi, Sosyal Bilimler Enstitusu Psikoloji Anabilim Dali. Master's Thesis, Diyarbakir, Dicle University.

Aycan, A., Polat, E., \& Ucan, Y. (2009). Takim Ozdeslesme Duzeyi Ile Profesyonel Futbol Musabakalarina Seyirci Olarak Katilim Kararini Etkileyen Degiskenler Arasindaki İliskinin İncelenmesi, Spormetre Beden Egitimi Ve Spor Bilimleri Journal, 11(4), 169-174. https://doi.org/10.1501/Sporm_0000000167

Babacan, M. E. (2015). Gencligin Sosyal Medya Kullanim Pratikleri ve Sosyal Sermaye Iliskisi, T.C. Genclik ve Spor Bakanligi Genclik Arastirmalari Journal, 3(2), 37-65.

Barboza, G. E., Schiamberg, L. B., Oehmke, J., Korzeniewski, S. J., Post L. A., \& Heraux, C. G. (2009). Individual Characteristics And The Multiple Contexts Of Adolescent Bullying: An Ecological Perspective. Youth Adolescent, 38(1), 101-121. https://doi.org/10.1007/s10964-008-9271-1

Bas, M. (2008). Futbolda Taraftar Ve Takim Ozdeslesmesi (Trabzonspor Ornegi). Saglik Bilimleri Enstitüsü, Beden Egitimi ve Spor Anabilim Dali. Phd Thesis, Ankara: Gazi University, 2008.

Batsche, G. M, \& Knoff, H. M. (1994). Bullies And Their Victims: Understanding A Pervasive Problem In the Schools. School Psychology Review, 23(2), 165-174.

Bayrak, H. (2019). 2019 Turkiye Internet Kullanim ve Sosyal Medya Istatistikleri, https://dijilopedi.com/2019-turkiye-internet-kullanim-ve-sosyal-medya-istatistikleri/, Accessed: 17. 06. 2019

Bayraktar, F. (2009). Ergenlerin Zorba ve Kurban Davranislarinda Birey, Aile, Akran ve Okula Iliskin Ozelliklerin Rolu: Butuncul Bir Model Onerisi. Sosyal Bilimler Enstitüsü, Psikoloji Anabilim Dali. Phd Thesis, Ankara: Hacettepe University

Berger, K. S. (2007). Update On Bullying At School: Science Forgotten. Developmental Review, 27(1), 90-126. https://doi.org/10.1016/j.dr.2006.08.002

Buch, R. D. (2012). Teachers' Perspectives on Bullying: Understanding Educational Intervention, Mankato, Minnesota State University, 6-7.

Craig W. M. (1998). The Relationship Among Bullying, Victimization, Depression, Anxiety, And Agression in Elementary School Children. Personal and Individual Differences, 24(1), 123-130. https://doi.org/10.1016/S0191-8869(97)00145-1

Craig, W., \& Pepler, D. (2003). Identifying and Targeting Risk for Involvement in Bullying and Victimization. Canadian Journal Of Psychiatry, 48, 577-582. https://doi.org/10.1177/070674370304800903

Crick. N. R., \& Bigbee, M. A. (1998). Relational and Overt Forms of Peer Victimization: A Multi Informant Approach. Journal of Consulting and Clinical Psychology, 66, 337-347. https://doi.org/10.1037/0022-006X.66.2.337

Duyar, D. (2011). Futbol Seyircisinde Saldirganlik Davranislarinin Incelenmesi. Saglik Bilimleri Ensitusu, Beden Egitimi ve Spor Anabilim Dali. Master's Thesis, Konya: Selcuk University. 
Eksisu, M. (2009). Liseli Ogrencilerin Zorbalik Duzeyleri ile Aile İslevleri ve Algilanan Sosyal Destek Arasindaki Iliskinin Incelenmesi. Sosyal Bilimler Enstitusu, Egitim Bilimleri Anabilim Dali. Master's Thesis, Istanbul: Istanbul University

Farrington, D. P. (1993). Understanding and Preventing Bullying. Inside: M. Tonry ve N. Morris (Ed). Crime and Justice (Vol.17). Chicago: University of Chicago Press. https://doi.org/10.1086/449217

Fekkes, M., Pijpers, F., \& Verlove-Vonherick, S. P. (2004). Bullying Behavior and Associations with Psychosomatic Complaint and Depression in Victims. The Journal of Pediatrics, 144(1), 17-22. https://doi.org/10.1016/j.jpeds.2003.09.025

Frisen, A., Jonsson, A., \& Persson, C. (2007). Adolescents' Perception of Bullying: Who is the Victim? Who is the Bully? What can Be Done to Stop Bullying? Adolescence, Winter, 42(168), 749-761.

Genc, G. (2007). Genel Liselerde Akran Zorbaligi ve Yonetimi. Sosyal Bilimler Ensitutusu, Egitim Bilimleri Anabilim Dali. Phd Thesis, Malatya: Inonu University

George, D., \& Mallery, P. (2010). SPSS for Windows Step by Step: A Simple Guide and Reference 17.0 Update. 10th Edition, Pearson, Boston

GSB, (2014). Genclik ve Sosyal Medya Arastirma Raporu, htp://www.gsb.gov.tr/

Hanish, L. D., \& Guerra, N. G. (2000). Children Who Get Victimized at School: What is Known? What Can be Done? Professional School Counseling; 4(2), 113-119.

Irfaner, S. (2009). Ogrenciler Arasinda Gerceklesen Zorbalik Eylemleri ve Zorbalik Konusunda Ogrencilerin, Ogretmenlerin ve Okul Yoneticilerinin Tutum ve Gorusleri. Sosyal Bilimler Ensititusu. Egitim Bilimleri Anabilim Dali. Phd Thesis, Ankara: Hacettepe University

Karaca, Y. (2019). Spor Seyircilerinin Zorbalik Davranislarinin Incelenmesi (Futbol Taraftari Ornegi), Inonu Universitesi ve Ankara Universitesi Beden Egitimi ve Spor Anabilim Dali Ortak Doktora Programi, Unpublished Phd Thesis, Malatya

Karasar, N. (1998). Bilimsel Arastirma Yontemi. 8. Basim. Ankara: Nobel Yayim Dag. Ltd.St.

Koc, Z. (2006). Lise Ogrencilerinin Zorbalik Duzeylerinin Yordanmasi. Egitim Bilimleri Enstitusu, Rehberlik ve Psikolojik Arastirmalar Anabilim Dali. Phd Thesis, Ankara:

Kumpulainen, K., Rasanen, E., \& Puura, K. (2001). Psychiatric Disorders and the Use of Mental Health Services among Children Involved in Bullying. Aggressive Behavior, 27, 102-110. https://doi.org/10.1002/ab.3

Lenhart, A. (2007). Cyberbulling http://www.pewinternet.org /27/06/2007/ cyberbullying/1, Accessed: 3. 09. 2018.

Mann, L. (1981). The Baiting Crowdin Episodes of Threatened Suicide. Journal of Personality and Social Psychology, 41(4), 703-709. https://doi.org/10.1037//0022-3514.41.4.703

Mishna, F. (2003). Peer Victimization: The Case for Social Work Intervention. Families in Society, 84(4), 513-522. https://doi.org/10.1606/1044-3894.142

Nansel, T. R, Overpeck, M., Pilla, R. S., Ruan, W. J., Simons-Morton, B., \& Scheidt, P. (2001). Bullying Behaviors among US Youth: Prevalence and Association with Psychosocial Adjustment. Journal of the American Medical Association; 285(16), 2094-100. https://doi.org/10.1001/jama.285.16.2094

Natvig, G. K., Albregtsen, G., \& Qvarnstrom, U. (2001). Psychosomatic Symptoms among Victims of School Bullying. Journal of Health Psychology, 6(4), 365-367. https://doi.org/10.1177/135910530100600401

Olweus, D. (1993). Bullying at School. What We Know and What We can Do. Oxford, UK: Blackwell

Olweus, D. (1999). The Nature of School Bullying. A cross-national perspective, London and New York: Routledge, 7-27.

Pellegrini, A. D., \& Long, J. D. (2002). A Longitudinal Study of Bullying, Dominance and Victimization during the Transition from Primary School through Secondary School. British Journal of Developmental Psychology, 20(2), 259-280. https://doi.org/10.1348/026151002166442

Salih, C. (2018). Turkiye Internet Kullanim ve Sosyal Medya Istatistikleri, https://dijilopedi.com/2018-turkiye-internet-kullanim-ve-sosyal-medya istatistikleri/ (www.com) 11-12-2018

Satan, A. (2006). Ilkogretim Ikinci Kademe Ogrencilerinin Zorba Davranis Egilimlerinin Okul Turu ve Bazi Sosyo Demografik Degiskenler Ile Iliskisi. Egitim Bilimleri Enstitusu. Phd Thesis, Istanbul, Marmara University.

Scheithauer, H., Hayer, T., Petermann, F., \& Jugert, G. (2006). Physical, Verbal and Relational Forms of Bullying 
Among German Students: Age, Trends, Gender Differences and Correlates. Aggressive Behavior, 32, 261-275. https://doi.org/10.1002/ab.20128

Serin, H. (2012). Ergenlerde Siber Zorbalik / Siber Magduriyet Yasantilari ve Bu Davranislara İliskin Ogretmen Ve Egitim Yoneticilerinin Gorusleri. Sosyal Bilimler Enstitusu, Egitim Bilimleri Anabilim Dali. Phd Thesis, Istanbul: Istanbul University

Sipahi, T. H. (2008). Izmir Ili Bornova Ilcesinde Ilkogretim 6. ve 7. Sinif Ogrencilerinde Akran Zorbaligi, Etkileyen ve Eslik Eden Faktorler. Saglik Bilimleri Enstitusu, Halk Sagligi Anabilim Dali. Phd Thesis, Izmir: Ege Üniversity

Stein, J. A., Dukes, R. L., \& Warren, J. I. (2007). Adolescent Male Bullies, Victims and Bully-Victims: A Comparison of Psychosocial and Behavioral Characteristics. Journal of Pediatric Psychology, 32(3), 273-282. https://doi.org/10.1093/jpepsy/js1023

Suslu, D. P. (2016). Lise Ogrencilerinin Siber Zorbalik ve Siber Magduriyetin Benlik Saygisi Anne Baba ve Akran Iliskileri Acisindan Incelenmesi. Sosyal Bilimler Enstitusu, Psikoloji Anabilim Dali. Phd Thesis, Istanbul: Istanbul Maltepe University

Tabachnick, B. G., \& Fidell, L. S. (2013). Using Multivariate Statistics (6th ed.). Boston, MA: Pearson.

Tham, A., Croy, G., \& Mair, J. (2013). Social Media in Destination Choice: Dinstinctive Electronic Word-Of-Mouth Dimensions, Journal of Travel and Tourism Marketing, 30, 144-155. https://doi.org/10.1080/10548408.2013.751272

Turgut, M. (2006). Fenerbahce Spor Kulubu Orgutlu Taraftarlarinin Taraftarlik Anlayislari Uzerine Bir Arastirma. Saglik Bilimleri Enstitusu, Beden Egitimi ve Spor Anabilim Dali. Phd Thesis, Ankara: Gazi University.

Wakefield, K. L., \& Sloan, H. J. (1995). "The Effects of Team Loyalty and Selected Stadium Factors on Spectator Attendance”, Journal of Sport Management, 9(2), 153-172. https://doi.org/10.1123/jsm.9.2.153

Wann, D. L. (1998).A Preliminary Investigation of the Relationship between Alcohol Use and Sport Fandom. Social Behavior and Personality, 26(3), 287-290. https://doi.org/10.2224/sbp.1998.26.3.287

\section{Copyrights}

Copyright for this article is retained by the author(s), with first publication rights granted to the journal.

This is an open-access article distributed under the terms and conditions of the Creative Commons Attribution license which permits unrestricted use, distribution, and reproduction in any medium, provided the original work is properly cited. 